\title{
PEMBELAJARAN SAINS BERMUATAN KARAKTER ILMIAH DENGAN ALAT PERAGA BARANG BEKAS DAN ASESMEN KINERJA
}

\author{
Wahyu Kurniawati ${ }^{1}$, Setyo Eko Atmojo² \\ 1, 2 Program Studi Pendidikan Guru Sekolah Dasar, \\ Universitas PGRI Yogyakarta, Indonesia \\ E-mail: wahyunian@yahoo.co.id ${ }^{1}$
}

\begin{abstract}
Abstrak
Tujuan penelitian ini adalah mengembangkan pembelajaran sains bermuatan karakter ilmiah dengan alat peraga barang bekas dan asesmen kinerja. Jenis penelitian ini adalah penelitian dan pengembangan. Teknik pengumpulan data menggunakan angket, observasi dan tes. Teknik analisis data menggunakan analisis deskriptif persentase. Hasil penelitian menunjukkan bahwa kevalidan pernagkat pembelajaran hasil pengembangan memiliki nilai kevalidan( $\mathrm{Va}$ ) 4,23 yang berada pada kriteria valid $(4 \leq \mathrm{Va}<5)$. Karakter ilmiah dalam diri mahasiswa pada pembelajaran sains bermuatan karakter ilmiah dengan alat peraga barang bekas berada pada kategori baik dimana rata rata persentase karakter ilmiah pada masing masing Kelas $>70 \%$. Persentase rata rata aktivitas siswa berada pada kategori baik yaitu $>70 \%$. Kemampuan kognitif mahasiswa pada kelas A1 sebesar 84,44\% memiliki kemampuan kognitif baik dan sangat baik 13,33 \% mahasiswa dalam kategori cukup dan 2,22 \% siswa berada pada kategori kurang. Pada kelas A2 sebesar 80,43\% mahasiswa memiliki kemampuan kognitif baik dan sangat baik dan sisanya memilki kemampuan kognitif pada kategori cukup. Pada kelas A3 sebesar 89,13\% mahasiswa memiliki kemampuan kognitif baik dan sangat baik serta pada kelas A4 sebesar $93,33 \%$ mahasiswa memiliki kemampuan kognitif baik dan sangat baik san sisanya memiliki kemampuan kognitif cukup.
\end{abstract}

Kata Kunci: karakter ilmiah, asesmen, barang bekas.

\begin{abstract}
The purpose of this study is to develop the scientific character of science learning laden with props thrift and performance assessment. This type of research is research and development. The technique of collecting data using questionnaires, observation and tests. Data were analyzed using descriptive analysis percentage. The results showed that the validity of the learning pernagkat validity of the development value (Va) 4.23 which is the valid criterion $(4 \leq \mathrm{Va}<5)$. Scientific character within students in science learning laden scientific character with props used items that are in good category where the average percentage of scientific character on each Class of $>70 \%$. The average percentage of student activity is in the good category that is $>70 \%$. Cognitive abilities of students in the class A1 of $84.44 \%$ cognitive ability and very good $13.33 \%$ of the students in the category fairly and $2.22 \%$ of students are in the poor category. In the A2 grade of $80.43 \%$ of the students have the cognitive ability and very good and the rest have the cognitive abilities in the category enough. In the A3 grade of $89.13 \%$ of the students have the cognitive ability and very good as well as the A4 grade of $93.33 \%$ of the students have the cognitive ability and very good san rest have sufficient cognitive ability.
\end{abstract}

Keywords: scientific character, assessment, used goods. 


\section{PENDAHULUAN}

Hasil dari proses belajar salah satunya adalah adanya perubahan sikap dan perilaku. Untuk dapat menghasilkan perubahan perilaku mahasiswa setelah melakukan kegiatan belajar diperlukan seuatu kegiatan pembelajaran yang memiliki karakter khusus sehingga mampu memunculkan perubahan sikap dan perilaku mahasiswa. Departemen Pendidikan Nasional mencanangkan pendidikan karakter bagi peserta didik. Mendiknas, Mohammad Nuh meluncurkan tema penting. "Pendidikan Karakter untuk Membangun Keberadaban Bangsa" pada acara peringatan Hari Pendidikan Nasional, tanggal 2 Mei 2010). Pengertian karakter menurut Muchlas Samamidan Hariyanto (2011) mengemukakan bahwa karakter dimaknai sebagai nilai dasar yang membangun pribadi seseorang, terbentuk baik karena pengaruh hereditas maupun lingkungan, yang membedakan dengan orang lain, serta diwujudkan dalam sikap dan perilaku dalam kehidupan sehari-hari. $M$. Furqonhidayatullah (2009) Karakter adalah kualitas atau kekuatan mental atau moral, akhlak atau budi pekerti individu yang merupakan kepribadian khusus yang membedakan dengan individu yang lain (Jaya, Sadia, \& Arnyana, 2014; Sadia, 2013).

$$
\text { Karakter ilmiah dapat }
$$

dikembangkan melalui pembelajaran sains dengan memasukkannya dalam pembelajaran sains, karakter ilmiah tersebut adalah Kerja Keras, Rasa Ingin tahu, Peduli Lingkungan, Peduli Sosial, dan Tanggung Jawab. Proses pembelajaran sains bermuatan karakter ilmiah ini menggunakan alat peraga barang bekas yang bertujuan untuk mengimplementasikan karakter ilmiah dan konsep sains ini dilingkungan sebagai upaya mengatasi kerusakan lingkungan melalui pemanfaatan barang bekas manjadi alat peraga pembelajaran. Alat peraga didefinisikan sebagai alat bantu untuk mendidik atau mengajar supaya konsep yang diajarkan guru mudah dimengerti oleh mahasiswa dan menjadi alat bantu dalam proses pembelajaran yang dibuat oleh guru atau mahasiswa dari bahan sederhana yang mudah didapat dari lingkungan sekitar. Alat ini berfungsi untuk membantu mempermudah dalam mencapai kompetensi pembelajaran. Alat peraga IPA dapat diciptakan sesuai dengan konsep yang diajarkan dengan biaya yang terjangkau dari bahan sederhana yang mudah diperoleh bahkan dari bahan bekas pakai. Pengalaman menunjukkan bahwa pembelajaran IPA yang menggunakan alat peraga lebih efektif dalam mencapai tujuan pembelajaran yang telah ditetapkan dibandingkan dengan tanpa menggunakan alat peraga.

Alat peraga merupakan perantara atau pengantar pesan pembelajaran. Pembelajaran menggunakan alat peraga berarti mengoptimalkan fungsi seluruh panca indra mahasiswa untuk meningkatkan efektivitas mahasiswa belajar dengan cara mendengar, melihat, meraba, dan menggunakan pikirannya secara logis dan realistis. Dengan demikian dapat dikatakan bahwa alat peraga merupakan wahana penyalur pesan atau informasi belajar. Melalui konsep yang semakin mantap itu, fungsi alat peraga dalam proses pembelajaran tidak hanya sekedar alat bantu guru melainkan pembawa pesan dari apa yang disampaikan oleh guru kepada mahasiswanya sesuai kebutuhan (A. Widiyatmoko dan S.D. Pamelasari, 2012). Alat peraga pembelajaran adalah sarana komunikasi dan interaksi antara guru dan mahasiswa dalam proses pembelajaran (Arsyad, 2005). Alat peraga pembelajaran adalah sesuatu yang dapat digunakan untuk menyampaikan pesan sehingga dapat merangsang pikiran, perasaan, perhatian, minat serta perhatian mahasiswa sehingga proses belajar mengajar terjadi (Taufiq, M., Dewi, N. R., \& Widiyatmoko, A. 2014). Oleh karena itu, keterampilan mahasiswa dalam memproduksi alat peraga perlu ditingkatkan terutama dengan biaya yang murah dan menggunakan bahan bekas pakai melalui pembelajaran sains bermuatan karakter ilmiah. 
Karakter ilmiah dalam pembelajaran sains sering dikaitkan dengan sikap terhadap sains. Keduanya saling berbubungan dan keduanya mempengaruhi perbuatan. Penilaian hasil belajar sains dianggap lengkap jika mencakup aspek kognitif, afektif, dan psikomotor. Sikap merupakan tingkah laku yang bersifat umum dilakukan mahasiswa. Tetapi sikap juga merupakan salah satu yang berpengaruh pada hasil belajar mahasiswa. Keterampilan ilmiah, karakter ilmiah dan sikap ilmiah memiliki peran yang penting dalam menemukan konsep sains. Mahasiswa dapat membangun gagasan baru sewaktu mereka berinteraksi dengan suatu gejala. Pembentukan gagasan dan pengetahuan mahasiswa ini tidak hanya bergantung pada karakteristik objek, tetapi juga bergantung pada bagaimana mahasiswa memahami objek atau memproses informasi sehingga diperoleh dan dibangun suatu gagasan baru. Karakter ilmiah dibedakan dari sekedar sikap terhadap sains, karena sikap terhadap sains hanya terfokus pada apakah mahasiswa suka atau tidak suka terhadap pembelajaran sains. Tentu saja sikap positif terhadap pembelajaran sains akan memberikan kontribusi tinggi dalam pembentukan karakter ilmiah tetapi masih ada faktor lain yang memberikan kontribusi yang cukup berarti.

Untuk mengetahui hasil dari proses pembelajaran sains yang bermuatan karakter ilmiah dengan alat peraga barang bekas diperlukan suatu alat evaluasi khusus yang memungkinkan untuk melihat kinerja mahasiswa selama melakukan kegiatan pembelajaran dan proses pembuatan alat peraga barang bekas. Untuk dapat menilai kinerja mahasiswa selam pembelajaran sains bermuatan karakter ilmiah dengan alat peraga barang bekas digunakan lembar penilaian kinerja (asesmen kinerja). Lembar penilaian ini menilai kinerja mahasiswa dalam mrancang, membuat dan penggunaan alat peraga yang telah dibuat beserta hasil nya yang berupa alat peraga pembelajaran sains dengan bahan barang bekas yang ada dilingkungan. Fitur yang akan dikembangkan adalah perangkat pembelajaran sains bermuatan karakter ilmiah yang terdiri dari silabus, SAP, bahan ajar, alat peraga barang bekas, dan lembar penilaian kienerja (asesmen kinerja). Tujuan utama dari penelitian ini adalah mengembangkan pembelajaran sains bermuatan karakter ilmiah dengan alat peraga barang bekas dan asesmen kinerja. Tujuan khususnya adalah: a) Mengembangkan pembelajaran sains bermuatan karakter ilmiah (kerja keras, rasa ingin tahu, peduli lingkungan, peduli sosial, dan tanggung jawab) dengan alat peraga barang bekas dan asesmen kinerja mahasiswa selama pembelajaran dan pembuatan alat peraga barang bekas. b) Meningkatkan pemahaman dan keterampilan mahasisawa mengenai konsep, prinsip dan praktek pembuatan alat peraga barang bekas. Pemberian pengetahuan tentang sains tentunya akan berbeda dengan pemberian pengetahuan selain sains, sains hanya dapat dipahami dengan maksimal ketika mahasiswa belajar dengan melakukan, menamukan konsep dan mempraktekannya.

Melalui pembelajarn sains bermuatan karakter ilmiah dan pembuatan alat peraga barang bekas dapat memberikan pengalaman belajar sains yang lengkap pada mahasiswa. Selain membrikan pengalaman pembelajaran sains bermuatan karakter ilmiah dengan alat peraga barang bekas dan asesmen kinerja juga akan dapat melatih mahasiswa untuk bekerja secara ilmiah sehingga akan membentuk karakter ilmiah mahasiswa. Dengan demikian mahasiswa akan memperoleh pemahaman yang lengkap sebagai hasil belajar sains yang maksimal serta memilki kinerja dan karakter ilmiah. Dengan memahami sains serta memiliki kinerja dan karakter ilmiah mahasiswa akan dapat memanfaatkan sumber sumber kekayaan alam di kemudian hari secara arif, kritis dan bijaksana tanpa harus merusak lingkungan dan kelestariannya atau bahkan mampu menemukan pengganti sumber daya alam yang tidak terbaharukan. 


\section{METODE}

Jenis penelitian yang akan dilakukan adalah penelitian pengembangan (research and development). Pengembangan yang dilakukan adalah pada perangkat pembelajaran sains bermuatan karakter ilmiah dengan alat peraga barang bekas dan asesmen kinerja. Penelitian pengembangan ini dilakasanakan di universitas PGRI Yogyakarta pada tahun 2016 dengan subjek penelitian mahasiswa PGSD angkatan 2015.
Penelitian ini akan dilaksanakan selama 12 bulan, pada tahun 2016 .

Penelitian ini menggunakan pendekatan research and development (penelitian dan pengembangan) yang dikemukakan oleh (Thiagarajan dalam Trianto, 2010). Implementasi langkah penelitian yang dikemukakan Thiagarajan dalam penelitian ini dimodifikasi menjadi tiga tahap. Jenis data, teknik pengumpulan data, instrumen dan teknik analisis data dapat dilihat pada Tabel 1.

Tabel 1. Jenis, teknik pengumpulan, instrument dan analisis data

\begin{tabular}{|c|c|c|c|c|}
\hline No & Jenis data & $\begin{array}{c}\text { Teknik } \\
\text { pengumpulan } \\
\text { data }\end{array}$ & $\begin{array}{c}\text { Instrumen } \\
\text { pengumpulan } \\
\text { data }\end{array}$ & Analisis data \\
\hline 1 & $\begin{array}{l}\text { Validitas } \\
\text { Perangkat } \\
\text { pembelajaran dan } \\
\text { aesemen kinerja }\end{array}$ & Angket validasi & $\begin{array}{l}\text { Lembar } \\
\text { validasi }\end{array}$ & Deskriptif persentase \\
\hline 2 & Karakter IImiah & Observasi & $\begin{array}{l}\text { Pedoman } \\
\text { observasi }\end{array}$ & Deskriptif persentase \\
\hline 3 & $\begin{array}{l}\text { Aktivitas } \\
\text { mahasiswa }\end{array}$ & Observasi & $\begin{array}{l}\text { Pedoman } \\
\text { observasi }\end{array}$ & Deskriptif persentase \\
\hline 4 & $\begin{array}{l}\text { Kemampuan } \\
\text { kognitif }\end{array}$ & Tes & $\begin{array}{l}\text { Lembar Soal } \\
\text { Tes }\end{array}$ & Deskriptif persentase \\
\hline 4 & $\begin{array}{l}\text { Respons } \\
\text { mahasiswa }\end{array}$ & Angket & Lembar angket & Deskriptif persentase \\
\hline
\end{tabular}

Hasil observasi aktivitas mahasiswa dalam pembelajaran Sains bermuatan karakter ilmiah dengan alat peraga barang bekas dapat dilihat pada Tabel 2. Berdasarkan Tabel 2 dapat dilihat bahwa seluruh aspek karakter ilmiah dalam diri mahasiswa telah muncul dalam kegiatan pembelajaran meskipun dengan persentase yang berbeda antara aspek karakter ilmiah satu dan aspek karakter ilmiah yang lain serta berbeda pula pada setiap kelas.

Tabel 2. Persentase Aktivitas mahasiswa Pada Tiap Aspek Keaktifan

\begin{tabular}{|c|c|c|c|c|c|}
\hline \multirow{2}{*}{ No } & \multirow{2}{*}{ Aspek keaktifan } & Kelas A1 & Kelas A2 & Kelas A3 & Kelas A4 \\
\hline & & $\%$ & $\%$ & $\%$ & $\%$ \\
\hline 1 & Merumuskan maasalah & 76,19 & 66,67 & 71,88 & 76,67 \\
\hline 2 & Menganalisis argumen & 71,43 & 73,33 & 65,63 & 80,00 \\
\hline 3 & $\begin{array}{l}\text { Menanyakan dan menjawab } \\
\text { pertanyaan }\end{array}$ & 47,62 & 46,67 & 43,75 & 83,33 \\
\hline 4 & $\begin{array}{l}\text { Mekarakter ilmiah siswa } \\
\text { Kebenaran Sumber Informasi }\end{array}$ & 52,38 & 63,33 & 53,13 & 73,33 \\
\hline 5 & $\begin{array}{l}\text { Melakukan observasi dan } \\
\text { membuat laporan }\end{array}$ & 42,86 & 50,00 & 65,63 & 76,67 \\
\hline 6 & Membuat deduksi & 100,00 & 100,00 & 96,88 & 100,00 \\
\hline 7 & Membuat induksi & 66,67 & 50,00 & 68,75 & 83,33 \\
\hline 8 & Mengevaluasi & 100,00 & 100,00 & 96,88 & 76,67 \\
\hline
\end{tabular}




\begin{tabular}{cccccc}
\hline \multirow{2}{*}{ No } & \multirow{2}{*}{ Aspek keaktifan } & Kelas A1 & Kelas A2 & Kelas A3 & Kelas A4 \\
\cline { 3 - 6 } & & $\%$ & $\%$ & $\%$ & $\%$ \\
\hline 9 & Mendefinisikan & 100,00 & 100,00 & 96,88 & 100,00 \\
10 & Mengidentifikasi asumsi & 85,71 & 73,33 & 75,00 & 83,33 \\
11 & Memutuskan dan & 85,71 & 53,33 & 62,50 & 80,00 \\
& melaksanakan & & & \\
\multirow{2}{*}{12} & Berinterkasi dengan orang & 100,00 & 100,00 & 93,75 & 100,00 \\
\hline
\end{tabular}

Berdasarkan Tabel 2 dapat diketahui bahwa aktivitas yang paling banyak dilakukan oleh mahasiswa adalah terlibat pada saat membuat deduksi, mendefinisikan dan berinetarksi dengan orang lain. Ketiga aspek keaktifan tersebut dilakukan oleh seluruh mahasiswa pada kelas A1, A2, dan $A 3$, sedangkan pada kelas $A 3$ tidak ada satu aspek yang dilakukan oleh seluruh mahasiswa dalam satu kelas. Aspek aktivitas yang paling rendah yaitu aspek menanyakan kepada anggota kelompoknya jika ada permasalahan yang tidak dimengerti dan memberikan pertanyaan yang sesuai dengan hasil presentasi diskusi kelompok lain yang hanya dilakukan oleh 43,75\% mahasiswa di kelas A3. Berdasarkan hasildiperoleh dapat diketahui bahwa rata rata persentase aktivitas mahasiswa pada Kelas A1 sebesar $77,62 \%$, pada kelas A2 sebesar
$72,33 \%$, pada Kelas A3 sebesar 73,44\% dan pada Kelas A4 sebesar 78,13\% yang termasuk pada kategori baik. Hal tersebut dapat diartikan bahwa rata-rata persentase aktivitas mahasiswa berada pada kategori baik. Hal tersebut menunjukkan bahwa pembelajaran sains bermuatan karakter ilmiah dengan alat peraga barang bekas efektif diterapkan di kelas karena persentase rata-rata aktivitas siswa berada pada kategori baik yaitu $>70 \%$ siswa aktif selama kagiatan pembelajaran berlangsung. Untuk mengetahui apakah pembelajaran sains bermuatan karakter ilmiah dengan alat perga barang bekas tepat untuk diimplementasikan dalam pembelajaran disebarkan angket ketepatan pembelajaran kepada mahasiswa di empat kelas tersebut. Hasil perhitungan angket ketepatan pembelajaran yang diberikan pada mahasiswa dapat dilihat pada Tabel 3.

Tabel 3. Hasil Perhitungan Angket Ketepatan Pembelajaran

\begin{tabular}{ccccccc}
\hline \multirow{2}{*}{ No } & \multirow{2}{*}{ Skor } & \multirow{2}{*}{ Kriteria } & Kelas A1 & Kelas A2 & Kelas A3 & Kelas A4 \\
\cline { 4 - 6 } & & $\%$ & $\%$ & $\%$ & $\%$ \\
\hline 1 & $17-20$ & Sangat tepat & 62,34 & 52,33 & 53,57 & 66,35 \\
2 & $13-16$ & Tepat & 34,45 & 45,25 & 37,48 & 32,43 \\
3 & $9-12$ & Kurang Tepat & 3,21 & 2,42 & 8,95 & 1,22 \\
4 & $5-8$ & Tidak tepat & 0 & 0 & 0 & 0 \\
& & Jumlah & $\mathbf{1 0 0}$ & $\mathbf{1 0 0}$ & $\mathbf{1 0 0}$ & $\mathbf{1 0 0}$ \\
\hline
\end{tabular}

Dapat diketahui dari Tabel 3 bahwa 96,79 \% mahasiswa pada Kelas $\mathrm{A} 1,97,58 \%$ mahasiswa pada kelas $\mathrm{A} 2$, $91,05 \%$ pada mahasiswa kelas A3 dan $98,78 \%$ pada mahasiswa kelas A4 menyatakan bahwa pembelajaran sains bermuatan akarkter ilmiah dengan alat peraga barang bekas tepat untuk diterapkan dalam pembelajaran di kelas I sekolah dasar. Berdasarkan perhitungan tersebut maka dapat diartikan bahwa pembelajaran sains bermuatan karakter ilmiah dengan alat peraga barang bekas tepat diterapkan dan memiliki tingkat keterterapan yang baik karena $>80 \%$ siswa memberikan tanggapan positif terhadap pembelajaran sains bermuatan karakter ilmiah dengan alat peraga barang bekas.Kemampuan kognitif mahasiswa dalam penelitian ini diukur menggunakan soal tes yang diberikan 
pada pertengahan semester (Ujian Tengah Semester) yang didalmnya mencakup materi materi yang diajarkan menggunakan pembelajaran sains bermuatan karakter ilmiah dengan aalat peraga barang bekas. Hasil perhitungan terhadap hasil tes kognitif mahasiswa dapat dilihat pada Tabel 4 .

Tabel 4. Kemampuan Kognitif Mahasiswa

\begin{tabular}{cccccc}
\hline Nilai & Huruf & Kelas A1 & Kelas A2 & Kelas A3 & Kelas A4 \\
\hline $81-100$ & A & 17 & 15 & 18 & 16 \\
$60-80$ & B & 21 & 22 & 23 & 26 \\
$41-59$ & C & 6 & 9 & 5 & 3 \\
$21-39$ & D & 1 & 0 & 0 & 0 \\
$0-20$ & E & 0 & 0 & 0 & 0 \\
Jumlah & & $\mathbf{4 5}$ & $\mathbf{4 6}$ & $\mathbf{4 6}$ & $\mathbf{4 5}$ \\
\hline
\end{tabular}

Berdasarkan Tabel 4 dapat diketahui bahwa kemampuan kognitif mahasiswa pada kelas A1 sebesar $84,44 \%$ memiliki kemampuan kognitif baik dan sangat baik 13,33\% mahasiswa dalam kategori cukup dan $2,22 \%$ siswa berada pada kategori kurang. Pada kelas A2 sebesar $80,43 \%$ mahasiswa memiliki kemampuan kognitif baik dan sangat baik dan sisanya memilki kemampuan kognitif pada kategori cukup. Pada kelas A3 sebesar 89,13\% mahasiswa memiliki kemampuan kognitif baik dan sangat baik serta pada kelas A4 sebesar 93,33\% mahasiswa memiliki kemampuan kognitif baik dan sangat baik dan sisanya memiliki kemampuan kognitif cukup.

\section{HASIL DAN PEMBAHASAN}

Penelitian ini merupakan penelitian pengembangan yang diklakukan dengan langkah langkah Four $D$ model yang terdiri dari empat tahap, yaitu pendifinisian (define), perancangan (design) pengembangan (develop), sedangkan tahap keempat, yaitu penyebaran (disseminate) tidak dilakukan. Tahap disseminate tidak dilakukan karena model pengembangan yang digunakan dalam mengembangkan perangkat pembelajaran telah di modifikasi pada kegiatan yang terkandung dalam setiap langkah dan fase Four-D, bukan sekadar mengubah dari empat tahap menjadi tiga tahap tetapi juga mencirikan proses dan kekhasan kegiatan dalam langkah-langkah penelitian yang dilakukan peneliti (Rohmad, 2011). Hasil dari pengembangan ini adalah berupa perangkat pembelajaran sains bermuatan karakter ilmiah dengan alat peraga barang bekas dan asesmen kinerja. Perangkat pembelajaran yang dikembangkan memiliki tingkat kevalidan yang baik dimana berdasarkan penilaian validator memperoleh skor validasi ( $\mathrm{Va}$ ) adalah 4,23 berada pada kriteria valid $(4 \leq \mathrm{Va}<$ 5) sehingga perangkat pembelajaran hasil pengembagan dapat diimplementasikan untuk menguji efektivitas perangkat pembelajaran hasil pengembangan tersebut. Perangkat pembelajaran sains bermuatan karakter ilmiah ini diimplementasikan dalam perkuliahan IPA di kelas pada mahasiswa progarm studi PGSD Universitas PGRI Yogyakarta.

Selama tahap pengembangan terdapat beberapa perbaikan pada perangkat pembelajaran yang di kembangkan. Perbaikan dari ahli tersebut antara lain pada bagian kegiatan perencanaan pembelajaran dimana bentuk perbaikan atau revisi dari ahli agar menentukan karakter ilmiah apa saja yang ada dalam kegiatan pembelajaran sains bermuatan karakter ilmiah yang dilaksanakan mahasiswa dalam masing masing pertemuan. 
Perbaikan kedua yaitu pada Kegiatan mahasiswa pada LKM disarankan agar LKM dilengkapi petunjuk dan tambahkan pembagian/distribusi tugas kepada masing masing kelompok. Tentukan barang bekas dan cara pemanfaatannya. Tambahkan tujuan pembelajaran dan alokasi waktu pada LKM. Pada tahap implementasi terdapat revisi pada Kalimat pada petunjuk kegiatan dalam LKM tentang barang bekas yang digunakan perlu diperbaiki agar lebih mudah dipahami. Jumlah pertanyaan pada LKM perlu disesuaikan dengan alokasi waktu diskusi. Perbaikan terakhir yaitu pada alokasi waktu dengan menyesuaikan dan menambah Alokasi waktu untuk presentasi hasil pembuatan alata peraga dari barang bekas dan diskusi perlu ditambah agar semua kelompok dapat tampil maksimal. Setelah dilakukan beberapa perbaikan sesuai saran dan masukan dari ahli selanjutnya dilakukan implementasi pada kegiatan pembelajaran di kelas untuk menguji efektivitas perangakat pembelajaran hasil pengembangan tersebut.

Tahap pegujian efektivitas dilakukan di kelas A1, A2, A3 dan A4 angkatan 2015 pada mata kuliah IImu Pengetahuan Alam 1. Uji efektivitas dilakukan dalam empat kali pembelajaran di masing masing kelas. Hasil penelitian menunjukkan bahwa seluruh aspek karakter ilmiah dalam diri mahasiswa telah muncul dalam kegiatan pembelajaran meskipun dengan persentase yang berbeda antara aspek karakter ilmiah satu dan aspek karakter ilmiah yang lain serta berbeda pula pada setiap kelas. Berdasarkan hasil analisis diketahui bahwa persentase karakter ilmiah terbaik adalah pada Kelas A4 79,49\% dan persentase karakter ilmiah terendah adalah pada kelas $A 173,51 \%$.

$\mathrm{Hal}$ tersebut dapat diartikan bahwa karakter ilmiah dalam diri mahasiswa pada pembelajaran Sains bermuatan karakter ilmiah dengan alat peraga barang bekas berada pada kategori baik dimana rata rata persentase karakter ilmiah pada masing masing skolah dasar $>70 \%$. Selaian karakter ilmiah dalam pembelajaran menggunakan perangkat pembelajaran sains bermuatan karakter ilmiah ini juga di observasi aktivitas mahasiswa selama kegiatan pembelajaran. Berdasarkan hasil analisis diketahui bahwa aktivitas yang paling banyak dilakukan oleh mahasiswa adalah terlibat pada saat membuat deduksi, mendefinisikan dan berinetarksi dengan orang lain. Ketiga aspek keaktifan tersebut dilakukan oleh seluruh mahasiswa pada kelas A1, A2, dan $A 3$, sedangkan pada kelas $A 3$ tidak ada satu aspek yang dilakukan oleh seluruh mahasiswa dalam satu kelas.

Aspek aktivitas yang paling rendah yaitu aspek menanyakan kepada anggota kelompoknya jika ada permasalahan yang tidak dimengerti dan memberikan pertanyaan yang sesuai dengan hasil presentasi diskusi kelompok lain yang hanya dilakukan oleh 43,75\% mahasiswa di kelas A3. Berdasarkan hasil analisis data diketahui bahwa rata rata persentase aktivitas mahasiswa pada Kelas A1 sebesar $77,62 \%$, pada kelas A2 sebesar $72,33 \%$, pada Kelas A3 sebesar 73,44\% dan pada Kelas A4 sebesar 78,13\% yang termasuk pada kategori baik. Hal tersebut dapat diartikan bahwa rata rata persentase aktivitas mahasiswa berada pada kategori baik (Sari, A. M., \& Widiyatmoko, A. 2014, Fatimah, S. 2013). Hal tersebut menunjukkan bahwa pembelajaran sains bermuatan karakter ilmiah dengan alat peraga barang bekas efektif diterapkan di kelas karena persentase rata rata aktivitas siswa berada pada kategori baik yaitu > 70\% siswa aktif selama kagiatan pembelajaran berlangsung.

Implementasi pembelajaran sains bermuatan karakter ilmiah dengan alat peraga barang bekas dan Asesmen Kinerja juga berpengaruh terhadap hasil belajar IPA ditinjau dari sikap atau respon mahasiswa (Putri, S., Candiasa, I. M., Kom, M. I., \& Marhaeni, A. N. (2014), Novalia, R. (2015), Susila, I. K. (2012)). Selanjutnya untuk mengatahuai respons mahasiswa terhadap pembelajaran sains bermuatan karakter ilmiah ini diberikan angket pada masing masing kelas pada 
akhir pembeljaran. Berdasarkan hasil analisis data angket respons siswa diketahui bahwa 96,79\% mahasiswa pada Kelas A1, 97,58\% mahasiswa pada kelas A2, 91,05\% pada mahasiswa kelas A3 dan $98,78 \%$ pada mahasiswa kelas A4 menyatakan bahwa pembelajaran sains bermuatan kakarkter ilmiah dengan alat peraga barang bekas tepat untuk diterapkan dalam pembelajaran di kelas. Berdasarkan perhitungan tersebut maka dapat diartikan bahwa pembelajaran sains bermuatan karakter ilmiah dengan alat peraga barang bekas tepat diterapkan dan memiliki tingkat keterterapan yang baik karena > $80 \%$ siswa memberikan tanggapan positif terhadap pembelajaran sains bermuatan karakter ilmiah dengan alat peraga barang bekas.

Dalam pembelajaran sains bermuatan karakter ilmiah ini selain mengamati karakter ilmiah, aktivitas, dan respon juga melihat hasil belajar mahasiswa setelah melakukan kegiatan pembelajaran sains bermuatan karakter ilmiah ini. Kemampuan kognitif mahasiswa dalam penelitian ini diukur menggunakan soal tes yang diberikan pada pertengahan semester (Ujian Tengah Semester) yang didalmnya mencakup materi materi yang diajarkan menggunakan pembelajaran sains bermuatan karakter ilmiah dengan aalat peraga barang bekas. Berdasarkan analisiss hasil tes mahasiswa diketahui bahwa kemampuan kognitif mahasiswa pada kelas A1 sebesar $84,44 \%$ memiliki kemampuan kognitif baik dan sangat baik 13,33\% mahasiswa dalam kategori cukup dan 2,22\% siswa berada pada kategori kurang. Pada kelas A2 sebesar $80,43 \%$ mahasiswa memiliki kemampuan kognitif baik dan sangat baik dan sisanya memilki kemampuan kognitif pada kategori cukup. Pada kelas A3 sebesar $89,13 \%$ mahasiswa memiliki kemampuan kognitif baik dan sangat baik serta pada kelas A4 sebesar 93,33\% mahasiswa memiliki kemampuan kognitif baik dan sangat baik san sisanya memiliki kemampuan kognitif cukup.

Implementasi

perangkat pembelajaran sains bermuatan karakter ilmiah ini selaian berpengaruh terhadap karakter ilmiah mahasiswa, aktivitas, respon juga berpengaruh terhadap kemampuan kognitif mahasiswa. Dalam kegiatan pembelajaran mahasiswa terlibat aktif melakukan kegiatan pembelajaran sehingga memiliki pemahaman yang lebih baik dari mahasiswa yang belajar secara konvensional. Mahasiswa yang aktif dalam kegiatan pembelajaran akan memiliki pemahaman dan hasil belajar yang lebih baik dari siswa yang hanya mendengarkan penjelasan dosen dan pasif selama kegiatan pembelajaran berlangsung (Awang, H. \& Ramly, I., 2008; Priyantini, N. P. T., Sadia, D. I. W., \& Suastra, D. I. W., 2015).

Berdasarkan hasil observasi aktivitas mahasiswa dalam pembelajaran sains bermuatan karakter ilmiah diketahui bahwa aktivitas mahasiswa selama kegiatan pembelajaran menggunakan perangkat pembelajaran hasil pengembangan termasuk dalam kategori baik. Berdasarkan hal tersebut dapat diketahui bahwa aktivitas mahasiswa dalam kegiatan pembelajaran berdampak positif terhadap karakter ilmiah dan hasil belajar kognitif, sehingga semakin baik aktivitas dalam pembelajaran semakin baik pula hasil belajar yang dicapai. Hal ini sejalan dengan penelitian Radiansyah tahun 2010 Radiansyah yang mengukur aktivitas mahasiswa PGSD pada Universitas Lambung Mangkurat.

Terjadinya peningkatan aktivitas, munculnya karakter ilmiah dari dalam diri mahasiswa dan kemampuan kognitif mahasiswa dalam pembelajaran sains bermuatan karakter ilmiah menunjukkan bahwa perangkat pembelajaran yang telah dikembangkan tepat jika diterapkan di kelas (Wulan, A. R., 2008; Khusniati, M., 2014; Conrad, R., Geiser, F., Kleiman, A., Zur, B., \& Karpawitz-Godt, A., 2014; Butler, A., 2016; Itoyama, H., Mironov, A., Morozov, A., \& Morozov, A., 2012). Hasil analisis terhadap angket keterterapan terhadap pembelajaran yang telah diisi oleh siswa menunjukkan bahwa 
perangkat pembelajaran hasil pengembangan tepat untuk diterapkan di kelas karena $>80 \%$ siswa memberikan tanggapan positif terhadap pembelajaran sains bermuatan karakter ilmiah dengan alat peraga barang bekas dan asesmen kinerja. Pembelajaran sains bermuatan pendidikan karakter dapat memengaruhi keterampilan berpikir kreatif dan sikap ilmiah jika dilihat dari motivasi belajar (Sanjayanti, N. P. A. H., Sadia, W., \& Pujani, N. M., 2013; Chusnani, D., 2013).

Pembelajaran pembelajaran sains bermuatan karakter ilmiah ini penting sekali untuk diterapkan dan dikembangkan lebih lanjut karena pembelajaran melibatkan mahasiswa untuk aktif dalam pembelajaran, dapat meningkatkan nilai karakter ilmiah dalam diri mahasiswa, serta dapat membuat mahasiswa menjadi aktif di keempat kelas yang diuji coba, serta sesuai dengan tuntutan kurikulum yang dikembangkan. Implementasi perangkat pemeblajaran sains bermuatan karakter ilmiah ini membantu mahasiswa dalam mempelajari, menerapkan konsep sains, menerapkan dalam kehidupan, mengurangi pencemaran, meningkatkan kreativitas mahasiswa dan lebih memahami konsep sains yang berkaitan dalam kehidupan.

\section{SIMPULAN DAN SARAN}

Kesimpulan dari penelitian ini menunjukkan bahwa hasil pengembangan perangkat pembelajaran memperoleh skor 4,3 yang berada pada kategori valid. Perangkat pembelajaran hasil pengembangan efektif ditinjau dari karakter ilmiah mahasiswa, aktivitas mahasiswa, dan hasil belajar kognitif mahasiswa yang bearada pada kategori baik dengan rata rata persentase $>70 \%$. Perangkat pembelajaran hasil pengembangan dapat diterapkan dengan baik dilihat dari angket yang diisi siswa menyatakan bahwa 96,79\% mahasiswa pada Kelas A1, 97,58\% mahasiswa pada kelas A2, 91,05\% pada mahasiswa kelas A3 dan 98,78\% pada mahasiswa kelas A4 menyatakan bahwa pembelajaran sains bermuatan akarkter ilmiah dengan alat peraga barang bekas tepat untuk diterapkan dalam pembelajaran di kelas.

Pembelajaran sains bermuatan karakter ilmiah dengan alat peraga barang bekas dan asesmen kinerja penting sekali untuk diterapkan dan dikembangkan lebih lanjut karena pembelajaran melibatkan mahasiswa untuk aktif dalam pembelajaran, dapat meningkatkan karakter ilmiah dalam diri mahasiswa, serta dapat membuat mahasiswa menjadi aktif di keempat kelas, serta sesuai dengan tuntutan kompetensi mata kuliah yang harus dicapai.

\section{DAFTAR RUJUKAN}

Arsyad, A. (2005). Media pembelajaran. Jakarta: Tim Abdi Guru Erlangga.

Awang, H. \& Ramly, I. (2008). Creative Thinking Approach Through Problem Based Learning Pedagogy and Practise in the Engineering Classroom. International Journal of Social Sciences, 3(1).

Butler, A. B. (2016). Dynamics of integrating landscape values in landscape character assessment: the hidden dominance of the objective outsider. Landscape Research, 41(2), 239-252. https://doi.org/10.1080/01426397. 2015.1135315

Conrad, R., Geiser, F., Kleiman, A., Zur, B., \& Karpawitz-Godt, A. (2014). Temperament and character personality profile and illnessrelated stress in central serous chorioretinopathy. The Scientific World Journal. https://doi.org/10.1155/2014/6316 87

Darhim. (1997). Materi Pokok Media Pengajaran. Jakarta.

Fatimah, S. (2013). Peningkatan Kemampuan Mengelompokkan Bned Berdasarkan Warna Dengan Menggunakan Media Botl Susu Plastik Bekas Pada Kelompok A 


\section{TK.Dharma Wanita Persatuan Dohoagung Balongpanggang Gresik. JurnalUnesa, 2(1), 1-10.}

Hariyanto, M. S. dan. (2011). Konsep Dan Model Pendidikan Karakter. PT. Remaja Rosdakarya. Bandung: PT. Remaja Rosdakarya.

Itoyama, H., Mironov, A., Morozov, A., \& Morozov, A. (2012). Character Expansion for Homfly Polynomials lii: All 3-Strand Braids in the First Symmetric Representation. International Journal of Modern Physics A, 27(19), 1250099. https://doi.org/10.1142/S0217751X 12500996

Jaya, I. M., Sadia, I. W., \& Arnyana, I. B. P. (2014). Pengembangan Perangkat Pembelajaran Biologi Bermuatan Pendidikan Karakter dengan Setting Guided Inquiry untuk Meningkatkan Karakter dan Hasil Belajar Siswa SMP. Jurnal Pendidikan IPA, 4(1), 1-12.

Kemendikbud. (2012). Panduan Integrasi Pendidikan Karakter dalam Pembelajaran IPA di Sekolah Dasar. Jakarta.

Ketut, S. I. (2012). Pengembangan Instrumen Penilaian Unjuk Kerja (Performance Assesment) Laboratorium Pada Mata Pelajaran Fisika Sesuai Kurikulum Tingkat Satuan Pendidikan Sma Kelas X Di Kabupaten Gianyar. Jurnal Penelitian Dan Evaluasi Pendidikan, 2(2). Retrieved from http://119.252.161.254/ejournal/index.php/jurnal_ep/article/ view/375

Khusniati, M. (2014). Model Pembelajaran Sains Berbasis Kearifan Lokal Dalam Menumbuhkan Karakter Konservasi. Indonesian Journal of Conservation, 3(1), 67-74.

Novalia, R. (2015). Pengembangan Instrumen Asesmen Kinerja Pada Praktikum Pengaruh Konsentrasi Terhadap Laju Reaksi. FKIP.
Puskur. (2006). Kurikulum Tingkat Satuan Pendidikan. Jakarta: Depdiknas.

Putri, S., Candiasa, I. M., \& Marhaeni, A. A. I. N. (2014). Pengaruh implementasi metode inkuiri terbimbing berbasis asesmen kinerja terhadap hasil belajar IPA ditinjau dari sikap ilmiah siswa kelas VIII SMP Negeri 1 Tegallalang. Jurnal Penelitian Dan Evaluasi Pendidikan, 4(0). Retrieved from http://pasca.undiksha.ac.id/ejournal/index.php/jurnal_ep/article/ view/1371

Ruseffendi, E.T, dkk. (1992). Pendidikan Matematika 3. Depdikbud. Jakarta.

Sadia, I. W., Arnyana, I. B. P., \& Muderawan, I. W. (2013). Model Pendidikan Karakter Terintegrasi Pembelajaran Sains. Jurnal Pendidikan Indonesia.

Sadia, W. . (2013). Model Pendidikan Karakter Terintegrasi Pembelajaran Sains. Jurnal Pendidikan Indonesia, 2(1).

Sanjayanti, N. P. A. H., Sadia, W., \& Pujani, N. M. (2013). Pengaruh Model Contextual Teaching Learning Bermuatan Pendidikan Karakter Terhadap Keterampilan Berpikir Kreatif Dan Sikap Ilmiah Ditinjau Dari Motivasi Belajar. Jurnal Pendidikan IPA, 3(1).

Sari, A. M., \& Widiyatmoko, A. (2014). Pengembangan Alat Peraga Pemanasan Global Berbahan Bekas Pakai Untuk Menanamkan Karakter Peduli Lingkungan. Unnes Science Education Journal, 3(3).

Soelarko, R. M. (1995). Audio Visual Media Komunikasi IImiah Pendidikan Penerangan. Jakarta: BinaciptaTim.

Sofyan, S. (2012). Membumikan Pendidikan Nilai dalam Kehidupan di Keluarga Masyarakat dan 
Sekolah dengan Penuh Kesadaran. In Seminar Pendidikan Nilai.

Sri Narwanti. (2011). Pendidikan Karakter. Familia (Grup Relasi Inti Media).

Sudjana, N. (2002). Dasar dasar proses belajar mengajar. Bandung: Sinar Baru Algesindo.

Supriyadi. (2010). Teknologi Pembelajaan Fisika. Yogyakarta: FMIPA.

Surya, M. (1992). Psikologi Pendidikan. Bandung: Unit Percetakan Offset.

Taufiq, M., Dewi, N. R., \& Widiyatmoko, A. (2014). Pengembangan Media Pembelajaran Ipa Terpadu Berkarakter Peduli Lingkungan Tema "Konservasi" Berpendekatan Science-Edutainment. Jurnal Pendidikan IPA Indonesia, 3(2), 203-208.

https://doi.org/10.15294/jpii.v4i2.4 179

Titin Priyantini, N. P., Sadia, I. W., \& Suastra, I. W. (2015). Pengembangan Perangkat Pembelajaran Fisika Sma Bermuatan Karakter Dengan Setting Model Pembelajaran Sains Teknologi Masyarakat Dan Lingkungan Untuk Meningkatkan Karakter Dan Keterampilan Berpikir Kreatif Siswa. Jurnal Pendidikan IPA., 5(1).

Trianto. (2011). Model Pembelajaran Terpadu. Jakarta: Bumi Aksara.

Usman, M. Uzerdan Setiawati, L. (1993). Upaya Optimalisasi kegiatan Belajar Mengajar. Bandung: PT. Remaja Rosdakarya.

Widiyatmoko, A., \& Pamelasari, S. D. (2012). Pembelajaran berbasis proyek untuk mengembangkan ALAT peraga IPA dengan memanfaatkan bahan bekas pakai. Jurnal Pendidikan IPA Indonesia, 1(1), 51-56. https://doi.org/10.15294/.v1i1.2013

Wulan, A. R. (2008). Skenario Baru Bagi Implementasi Asesmen Kinerja pada Pembelajaran Sains di Indonesia. Jurnal Mimbar Pendidikan, 32(3), 1-11. 